\title{
AWM Awards Given in San Antonio
}

The Association for Women in Mathematics (AWM) presented several awards at the Joint Mathematics Meetings in San Antonio, Texas, in January 2015.

\section{Louise Hay Award}

The Louise Hay Award for Contributions to Mathematics Education recognizes outstanding achievements in any area of mathematics education. Louise Hay was widely recognized for her contributions to mathematical logic and for her devotion to students.

\section{Citation}

The 2015 Louise Hay Award for Contributions to Mathematics Education was presented to T. CHRistine STEVEns, professor of mathematics and computer science at Saint Louis University, in recognition of her outstanding contributions to the teaching and learning of mathematics. Stevens received her $\mathrm{PhD}$ from Harvard University under the direction of Andrew Gleason. She was cofounder and codirector, with James Leitzel, of Project NExT, a professional development program of the MAA for faculty in their first two years of full-time teaching. She was the sole director of Project NExT during the years 1998-2009, gradually adding recent Project NExT Fellows and others to the leadership team. More than 1,000 new faculty members participated in Project NExT under her leadership, about half of them women. Approximately 400 other faculty members have been involved with Project NExT as consultants and workshop presenters. Many fellows have gone on to win teaching awards of their own, often citing Project NExT as a factor in their success.

Her contributions to mathematics education are manifold. She has had an impact on national science policy through her service as an AMS/MAA/

DOI: http://dx.doi.org/10.1090/noti1245
SIAM Congressional Science Fellow, her chairing of the MAA's Science Policy Committee, and her service on the SIAM Science Policy Committee. She was an Associate Program Director for the Teacher Enhancement Program at NSF. She has been a strong advocate for expanding opportunities for underrepresented groups as a member of the MAA Committee on Minority Participation in Mathematics and on many other committees.

\section{Gweneth Humphreys Award for Mentorship of Undergraduate Women in Mathematics}

This award is named for M. Gweneth Humphreys (1911-2006). Humphreys graduated with honors in mathematics from the University of British Columbia in 1932, earning the prestigious Governor General's Gold Medal at graduation. After receiving her master's degree from Smith College in 1933, Humphreys earned her $\mathrm{PhD}$ at age twenty-three from the University of Chicago in 1935. She taught mathematics to women for her entire career. This award, funded by contributions from her former students and colleagues at Randolph-Macon Woman's College, recognizes her commitment to and her profound influence on undergraduate students of mathematics.

The 2015 award was presented to RUTH HAAS of Smith College. She has been a driving force in the strong and vibrant mathematics community at Smith, having nurtured and supported a generation of women mathematics students. An impressive alumnae body attests enthusiastically to the crucial role she played in their decision to major in mathematics, attend graduate school, and ultimately pursue careers in the mathematical sciences. Former students praise her unwavering support as they move on from Smith, pursue their careers, and face both personal and academic setbacks. Haas was instrumental in establishing the Center for 
Women in Mathematics and the highly successful postbaccalaureate program at Smith. She has developed and supported many other academic and community-building initiatives, including a highly effective undergraduate research course, the annual WIMIN conference (Women in Mathematics in the Northeast), a program for junior visitors, a high school outreach program, and weekly seminars. A sentence in her nomination letter reads: "Of the US citizen women earning doctorates in mathematics in 2013 from the top 100 graduate schools in America, 6 percent were mentored by Ruth Haas. From her position at a relatively small school, Ruth Haas is mentoring a sizable percentage of the new generation of American women mathematicians."

\section{Schafer Prize}

The Alice T. Schafer Prize for Excellence in Mathematics by an Undergraduate Woman is named for Alice T. Schafer (1915-2009), one of the founders of AWM and its second president, who contributed greatly to women in mathematics throughout her career. The criteria for selection include, but are not limited to, the quality of the nominee's performance in mathematics courses and special programs, an exhibition of real interest in mathematics, the ability to do independent work, and, if applicable, performance in mathematical competitions.

The 2015 Schafer Prize was presented to SHEELA DevaDAs of the Massachusetts Institute of Technology. As a sophomore in high school, Devadas joined a research group for high school students at MIT (PRIMES), where she was assigned a project on Cherednik algebras. As a fifteen-year-old, she quickly mastered the basics of representation theory, commutative algebra, and computer algebra systems. In 2011 she won a silver medal in the Advantage Testing Foundation Math competition for girls.

After completing her junior year of high school, Devadas began studying at MIT, taking many advanced mathematics courses, including Fourier analysis, arithmetic geometry, discrete mathematics, and graduate-level courses in randomness and computation, representation theory, cryptography, and commutative algebra. Continuing her work in representation theory, she is now coauthor of a paper to appear in the Journal of Commutative Algebra. Her mentors comment that this is an "excellent paper" and that her work is at a level far beyond her age. Devadas shows great breadth by also engaging in research in theoretical computer science, specifically homomorphism testing. These results are currently being written for publication.

Devadas is described as having the "highest level of imagination and skill"; an "outstanding student" who is "brilliant, and at the same time very hard working, mature, and motivated"; and having "a bright research career ahead of her." She is called "second to none" among "many amazing MIT undergraduates."

In addition, SAMANTHA PETTI of Williams College was honored as runner-up in the 2015 Schafer Prize competition. MADELINE BRANDT of Reed College was awarded Honorable Mention.

\section{AWM Service Award}

Four women were presented with the AWM Service Award, which recognizes individuals for helping to promote and support women in mathematics through exceptional voluntary service to the AWM. The award is given annually to selected volunteers in recognition of their extensive time and effort devoted to AWM activities during the previous seven years. The 2015 awardees are KATHRYN LEONARD, ELEBEOBA E. MAY, IRINA MitREA, and CHRISTINA SORMANI. Leonard, of California State University Channel Islands, was recognized for her active involvement with the AWM Meetings Committee and as principal investigator on the grant funding the AWM 2013 Research Symposium and the AWM Workshop at JMM 2014. May, of the University of Houston, was recognized for her active involvement with the AWM Meetings Committee and for helping to organize the AWM-SIAM workshops at the SIAM annual meetings. Mitrea, of Temple University, was honored for her service to AWM as a principal investigator on a successful NSF Sonia Kovalevsky Day grant and for her leadership of the team that organized the AWM activities at the 2010, 2012, and 2014 USA Science and Engineering Festivals. Sormani, of the City University of New York Graduate Center and Lehman College, was recognized for her active involvement with the AWM Meetings Committee as a member of the JMM Committee that oversees the AWM activities at the Joint Mathematics Meetings.

-AWM announcements 